\title{
Ketencik Bitkisinin (Camelia sativa) Kanatlı Beslenmesinde Kullanılması
}

\author{
Tugay AYAŞAN \\ Doğu Akdeniz Tarımsal Araştırma Enstitüsü, Adana
}

Geliş (Received): 01.07.2014

Kabul (Accepted): 14.07.2014

Özet: Kanatlı rasyonlarında mısır, soya küspesi ve balık unu gibi yem hammaddelerinin fiyatlarının artması, daha az pahalı olan alternatif kaynaklara olan ihtiyacı artırmıştır. Ketencik bitkisi biodizel kaynağı olarak son yıllarda popülaritesini artıran Brassica (Cruciferae) familyasından yağlı bir bitkidir. Biodizel üretimi için mısır ve diğer yağlı bitkilere olan yüksek talep düşünüldüğünde, protein ve enerji içeren alternatif yem kaynaklarının bulunması, broiler üretim maliyetini azaltacaktır. Bu derlemede ketencik bitkisi ile bu konuda kanatlı hayvanlar üzerinde yapılan besleme çalışmaları ele alınmıştır.

Anahtar kelimeler: Ketencik, Broiler, Yumurtacı tavuk, Yem, Besleme

\section{Use of Camelina (Camelina sativa (L.) Crantz) in Poultry Nutrition}

Summary: The increasing costs of conventional feedstuffs like corn, soybean meal and fish meal for poultry diets is pushing the need to find less expensive alternatives. Camelina sativa is an oilseed crop of the Brassica (Cruciferae) family that has gained increasing popularity as a biofuel source. Considering the high demand for corn and other oil crops for biofuel production, finding alternate sources of energy and protein will reduce broiler production costs. In this paper, feeding studies made on the camelina used in nutrition of poultries have been reviewed.

Key words: Camelina sativa, Broiler, Laying hens, Feed, Nutrition

\section{G R S}

Ketencik (Camelina sativa), Brassicaceae familyasinda yer alan, eski bir kültür bitkisidir. 2000 yıldır Avrupa'da yă̆ kaynağı ve çiftlik hayvanlarında kullanılmasına rağmen; bu ürün son yıllarda, içerdiği yağdan (\%28-45) dolayı biodizel kaynağı olarak popülaritesini artırmıştır. Bu ürüne gold of pleasure (False flax) adı da verilmektedir. Ülkemizde alternatif bir yağ bitkisi olan ketencik ilk yıllarda fazla olarak ekimi yapılırken; günümüzde üretimi azalmıştır. Bununla birlikte, düşük çevre isteği ve ürünlerinin yaygın olarak kullanılabilirliği sayesinde bu bitki büyük ilgi görmüştür.

Ketencik üretimi ülkemizde yapılmamakla beraber Almanya'da ekim alanı 1993 yıllında 95 ha iken, 1994 yıllında 138 ha, 1995 yılında 66 ha ve de1996 yıllında 17 ha olup yıllara göre inişli çıkışlı bir durum takip etmiştir. Ekim alanı ve üretim bakımından her ne kadar da dünya istatistiki verileri içerisinde yer bulamasa da 2013 yılı içerisinde Türk firmaları tarafından Rusya ve Ukrayna'dan çok miktarda ketencik ürünü ithal edilmiş ve işlenerek iç piyasaya sürülmüştür (Önder, 2013).

Yazlık ve tek yıllık bir ya $\breve{g}$ bitkisi olan ketencik (Camelina sativa (L.) Crantz) bitkisi yazlık olmakla birlikte sert kışlara dayanıklı tipleri de olan bir kültür bitkisi olup; günümüzde özelikle de Romanya' da ekimi yapılmaktadır. M.S. 1000'li yıllarda Türk illerinde "Mayıh, Mayec" ismi ile anılan ketencik, günümüzde "Yalanc1 Keten", "Alman Susamı", "Sibirya Yağl1 Tohumu" gibi değişik isimlerle de adlandırılmaktadır (Koç ve Önder, 2012).

Ketencik yağından ayrıca jet yakıtı da üretilmektedir. $\mathrm{Bu}$ nedenle de dünya havayolu şirketlerinin ilgisini çeken bir konu olmaya da devam etmektedir. Ketencik küspesi, protein, yağ ve esansiyel olan n-3 ve n-6 yağ asitlerince zengin bir yem maddesidir. Bu nedenle de yukarıdaki besinlere ilaveten enerji kaynağı olmasıyla birlikte kanatlı hayvanların yemlerine de katılmaktadır. Bu derlemede hayvan beslemede kullanılan ketencik bitkisi ve ondan elde edilen ürünlerle kanatlı hayvanlar üzerinde yapılan besleme çalışmaları ele alınmıştır.

\section{Ketencik Bitkisinin Besin Madde Kompozisyonu}

Ketencik bitkisel yağ kaynağıdır. Ketencik tohumu, yapısında $\% 38.9$ yağ, $\% 30 \alpha$-linolenik asit (18:3 n-3, omega-3 yağ kaynağı olarak), \%25.8 ham protein içermektedir. Yüksek yağ içeriği, omega-3 yağ asidi içermesi ve ham proteininden dolayı hayvan yemlerine de katıldı $\breve{g}_{1}$ bildirilmektedir (Cherian, 2012). Buna karşılık Toncea ve ark., (2013), ketencik tohumunun yapısında \%18.87-21.97 düzeyinde protein, \%30.10-49.70 arasında da yağ içerdiğini ifade etmişlerdir. Ketencik tohumunun kimyasal komposizyonu Çizelge 1'de verilmiştir.

Çizelge 1. Ketencik tohumunun kimyasal komposizyonu (Toncea ve ark., 2013)

\begin{tabular}{lc}
\hline Kimyasal kompozisyon & \% \\
\hline Protein, \% & $18.87-21.97$ \\
Yağ, \% & $30.10-49.70$ \\
Ham selüloz, \% & $11.06-15.24$ \\
Kül, \% & $4.25-5.24$ \\
Kalsiyum, \% & 0.18 \\
Fosfor, \% & 0.53 \\
Bakır, \% & 0.49 \\
Mangan, \% & 1.39 \\
Demir, \% & 4.47 \\
Çinko, \% & 2.56 \\
Vitamin E, mg/100 mg & $25.83-28.21$ \\
Vitamin $\mathrm{B}_{1}, \mathrm{mg} / 100 \mathrm{mg}$ & 0.20 \\
Vitamin $\mathrm{B}_{2}, \mathrm{mg} / 100 \mathrm{mg}$ & 0.55 \\
\hline
\end{tabular}


Ketencik tohumunun ya $\breve{g}$ oranını belirlemek üzere birçok çalışma yürütülmüş olup, genelde bitkinin yazlık çeşitlerinde \% 42 dolayında yă bulunurken, kışlık çeşitlerinde ise bu oran biraz daha yüksek olup \% 45'lere ulaşmıştır (Zubr, 1997; Kurt ve Seyis, 2008). Katar ve ark., (2012), farklı ekim zamanlarının ketencik (Camelina sativa (1.) crantz) bitkisinin yă oranı ve bileşimi üzerine olan etkisini belirlenmesi belirlemek amacıyla yaptıkları çalışmalarında ekim zamanlarına bağlı olarak yağ veriminin $0.32-129.78 \mathrm{~kg} / \mathrm{da}$ ve yă oranının da \% 20.57- 39.47 arasında değiştiğini ifade etmişlerdir. Protein ve selüloz, ketencik tohumunun en önemli besinsel parametrelerindendir. Tohumdaki ham protein \%18.87-21.97 arasında değişim gösterirken; ham selüloz içeriği \%11.06-15.24 arasında değer almaktadır. Ketencik tohumu yüksek düzeyde vitamin E (25.83-28.21 mg/100 g) içermekte olup, güçlü de bir antioksidanttır (Toncea ve ark., 2013).

\section{Ketencik Küspesinin Besin Madde Kompozisyonu}

Ketencik küspesi, protein, yağ ve esansiyel olan n-3 ve $n-6$ yağ asitlerince zengin bir yem maddesidir. Ketencik tohumunun yağı değişik yöntemlerle alındıktan sonra geriye kalan küspesi elde edilir. Ketencik küspesinin yağ asit komposizyonu yüksek düzeyde esansiyel yağ asitlerini içermesi nedeniyle dikkate alınmalıdır. Küspe, omega 3 ve omega 6 yağ asitlerince zengin bir kaynaktır. Omega 6/omega 3 yağ asiti oranı $0.90 / 0.70$ 'dir. $\alpha$-linolenik asit (18:3 n-3), temel omega 3 yağ asidi olup; ketencik küspesindeki oranı \%29.48' dir. Linoleik asit (C18:2n-6)' in oranı ise \%23.87'dir (Cherian, 2012). Çizelge 2'de ketencik küspesinin kimyasal komposizyonu gösterilmiştir.

Ketencik küspesinin aminoasit içeriğine bakıldığında (Çizelge 2), glutamik asidin \% 5.50; aspartik asidin de \% 2.84 ile en yüksek değerleri aldığı; buna karşılık triptofan düzeyinin \% 0.43 , tirozin düzeyinin de $\% 0.82$ ile en düşük değerleri aldığ görülmektedir.

Çizelge 3'de ketencik küspesi ile keten tohumunun besin madde ve aminoasitler bakımından karşılaştırılması verilmiştir (Patterson, 2011).

Anonymous, (2012), 2009 yilında FDA (The Food and Drog Administration)'nın ketencik küspesinin \% 10 'dan fazla olmamak şartıyla sığır, yumurtacı tavuk ve etlik piliçlerin yemlerine katılabileceğini; domuz yemlerine ise \% 2'den fazla olmamak şartıyla katılmasına izin verdiğini; bunun sebebinin ise yă içeriği olduğunu ifade etmiştir.

Etlik Civciv Ve Piliçlerde Ketencik Bitkisinin Kullanımı

Ketencik küspesi, protein, yağ ve esansiyel olan n-3 ve $\mathrm{n}-6$ yağ asitlerince zengin bir yem maddesidir. $\mathrm{Bu}$ nedenle de yukarıdaki besinlere ilaveten enerji kaynağı olmasıyla birlikte kanatlı hayvanların yemlerine katılmaktadır.

Çizelge 2. Ketencik küspesinin kimyasal komposizyonu (Cherian, 2012)

\begin{tabular}{lc}
\hline \multicolumn{1}{c}{ Kimyasal kompozisyon } & \% \\
\hline Ham Protein, \% & 36.2 \\
Yağ, \% & 11.5 \\
Ham Selüloz, \% & 8.4 \\
Gross enerji, kcal/kg & 4755 \\
Kül, \% & 6.5 \\
NDF, \% & 41.8 \\
\hline Mineraller & \\
Kalsiyum, ppm & 2703 \\
Fosfor, ppm & 10214 \\
Bakır, ppm & 9.18 \\
Mangan, ppm & 25.1 \\
Demir, ppm & 151 \\
Çinko, ppm & 61.1 \\
$\alpha$ tokopherol, $\mu \mathrm{g} / \mathrm{g}$ & 5.2 \\
Fenolikler, $\mu \mathrm{g} / \mathrm{g}$ & 4006 \\
Flavonoidler, mg/g & 21.2 \\
\hline Amino asitler & $\mathbf{\%}$ \\
Alanin & 1.60 \\
Arjinin & 2.16 \\
Aspartik asit & 2.84 \\
Fenilalanin & 1.47 \\
Glisin & 1.82 \\
Glutamik asit & 5.50 \\
Histidin & 0.84 \\
zolösin & 1.38 \\
Lösin & 2.32 \\
Lizin & 1.77 \\
Metionin & 0.92 \\
Serin & 1.36 \\
Sistin & 0.95 \\
Treonin & 1.34 \\
Tirozin & 0.82 \\
Valin & 1.89 \\
Triptofan & 0.43 \\
\hline Yağ Asitleri & 2.38 \\
Palmitic (C16:0) & 20.33 \\
Stearic (C18:0) & 23.87 \\
Oleik asit (C18:1) & 29.48 \\
Linoleik asit (C18:2n-6) & 10.67 \\
$\alpha$-Linolenik asit (C18:3n-3) & \\
Eicosenoik (C20:1) & \\
\hline & \\
\hline
\end{tabular}

Ketencik küspesinin yem kaynağı olarak kullanılması, onun kimyasal komposizyonu, besin değeri, sindirilebilirliği ve ürün kalitesi gibi özelliklerine bağlıdır. Bu nedenle et 1 rkı düvelerde (Moriel ve ark., 2011), süt 1rk1 ineklerde (Hurtaud ve Peyraud, 2007) ve koyunlarda (Szumacher-Strabel ve ark., 2011) çalışmalar yapılmıştır. Hurtaud ve Peyraud, (2007), ketencik tohumu veya küspesine dayalı yemlerin kuru madde tüketimini azaltma eğiliminde olduğunu, buna karşılık süt üretimi üzerine istatistiki bir farklılaşmaya yol açmadı ̆̆ını tespit etmişlerdir. 
Çizelge 3. Ketencik küspesi ile keten tohumunun besin madde ve aminoasitler bakımından karşılaştırılması (Patterson, 2011).

\begin{tabular}{lcc}
\hline Ketencik & $\begin{array}{c}\text { Keten tohumu } \\
\text { küspesi }\end{array}$ & \\
\hline $\begin{array}{l}\text { Besin madde } \\
\text { kompozisyonu, \% }\end{array}$ & & \\
Kuru madde & 92.02 & 93.68 \\
Ham protein & 34.99 & 23.44 \\
Ham yağ & 13.55 & 38.84 \\
Selüloz & 9.90 & 6.00 \\
Kül & 5.67 & 3.48 \\
\hline Esansiyel amino asitler, \% & & \\
Arginin & 2.86 & 2.20 \\
Lizin & 1.59 & 0.91 \\
Histidin & 0.83 & 0.51 \\
Fenilalanin & 1.44 & 1.08 \\
Metionin & 0.59 & 0.43 \\
Lözin & 2.20 & 1.35 \\
Valin & 1.75 & 1.16 \\
Treonin & 1.34 & 0.85 \\
\hline Esansiyel olmayan amino & & \\
asitler, \% & & \\
Glutamik asit & 5.74 & 4.46 \\
Aspartik asit & 2.83 & 2.18 \\
Alanin & 1.52 & 1.05 \\
Sistin & 0.74 & 0.41 \\
Serin & 1.51 & 1.06 \\
Glisin & 1.77 & 1.38 \\
\hline
\end{tabular}

Moriel ve ark., (2011), ketencik ürünlerinin gelişmekte olan et 1rkı düvelerin yemlerinde misırsoya küspesinin yerine başarıyla ikame edilebileceğini ifade ederken; Szumacher-Strabel ve ark., (2011), karma yeme eklenmesi durumunda koyunların sütündeki doymamış yağ asidi içeriğini artırdı ̆̆ını bildirmiştir.

Etlik piliçlerde ketencik bitkisinin ve ürünlerinin besi performansina olan etkisi konusunda yapilan çalışmalar sınırlıdır. Yapılan çalışmalarda ketencik tohumunun etlik piliçlerin yemlerine $\% 10$ ve 20 düzeyinde katılmasının performans üzerine olumsuz etkisinin olduğu ifade edilmiştir (Ajuyah ve ark., 1991; Gonzalez ve Leeson, 2001). Georgeta ve ark., (2007) ise, ketencik tohumunun bitiş dönemindeki etlik piliçlerin besi performansına olan etkisini araştırdıkları çalışmalarında, ketencik tohumlarının deneme sonu canlı ağırlığı azalttığını $(\mathrm{P}<0.05)$, buna karşılık yemden yararlanma oranı ile yaşama oranının etkilemediğini, karkas yağının azaldığını, toplam protein düzeyinin ise arttı̆̆ını tespit etmişlerdir.

Başlangıç periyodu esnasında \%10 ketencik küspesi ile beslenen etlik civcivlerde yemden yararlanmanın kötüleştiği, yem tüketiminin azaldı ̆̆ bildirilmektedir (Ryhänen ve ark., 2007; Pekel ve ark., 2009). Ketencik, yapısında yem tüketiminin etkileyen, yüksek düzeyde nişasta yapısında olmayan polisakkaritler ve glukosinolatları içermektedir.

Pekel ve ark., (2009), ilk 3 haftalık dönemdeki etlik civcivlerin yemlerine ketencik küspesinin \%10 düzeyinde katılması durumunda canlı ağırlığın azaldı̆̆ını tespit etmişlerdir. Buna karşılık Aziza ve ark., (2010a), karma yeme \%10 düzeyinde ketencik küspesinin katılmasının etlik piliçlerin beyaz ve koyu etindeki omega 3 yağ asidi düzeyini 2.5 kat artırmasına karşılık, canlı ağırlık üzerine bir etkisinin bulunmadığını ifade etmişlerdir.

Aziza ve ark., (2010b), \%10 düzeyinde ketencik küspesi katkısının but etindeki $\gamma$-tokoferol düzeyinde 1.5 katlık bir artışa neden olduğunu; but etindeki antioksidan aktivitede bir artışın oluştuğunu bildirmişlerdir.

Jaśkiewicz ve ark., (2010) ketencik tohumu yağı ve konjuge linoleik asidin etlik piliç yemlerinde ayçiçeği yağının yerine kullanılabileceğini, performans üzerine de etkisinin olumlu olduğunu bildirmişlerdir.

Puzio ve ark., (2012)'da karma yeme konjuge linoleik asit ile ketencik tohumu yağı katkısının kemik ölçütlerine olan etkilerini inceledikleri çalışmalarında femur ağırlığının, humerus ağırlığının, tibia ağırlığının, konjuge linoleik asit+ketencik tohumu yağı katılan grupta diğer gruplara göre yüksek olduğunu bildirmişlerdir.

\section{Yumurtacı Tavuklarda Ketencik Bitkisinin} Kullanımı

Yağlı tohumlar ve küspeleri yumurtacı tavukların yemlerine enerji, protein ve omega 3 yağ asidi kaynağ olarak katılmaktadır.

Bean ve Leeson (2003), yağlı tohumlar ve onlardan elde edilen küspelerin rasyonda \%10'dan daha az düzeyde bulunmasını tavsiye etmiştir.

Pilgerem ve ark., (2007), \%15 düzeyinde ketencik küspesi ile beslenmenin kanatlı sağlığı veya yumurta verimi üzerine olumsuz bir etkisinin bulunmadığını bildirirken; Cherian ve ark., (2009), karma yeme \%5, 10 ve 15 düzeyinde ketencik küspesinin katılmasının etkilerini araştırdıkları çalışmalarında; \%5 ve 10 düzeyinde katılan ketencik küspesinin yumurta verimi ve kabuk kalitesinde bir değişiklik yaratmadığını; \%15 düzeyinde katılması durumunda ise yumurta veriminde bir azalmanın oluştuğunu bildirmişlerdir

Ketencik küspesinin yemlere $\% 10$ 'un üzerinde katılması büyüme performansı ve yem tüketimini, et ve yumurta kalitesini etkilemezken; $\% 10$ düzeyinde ketencik küspesi ile besleme, tavuk etinde omega 3 yağ asitinin 3 kat; tavuk yumurtasinda ise 8 kat artmasina yol açmıştır (Cherian, 2012).

\section{SONUC}

Ketencik bitkisi ve ürünlerinin kanatlı beslemede kullanılabileceği ancak ülkemizde bu konuda çalışma yapılmasının gerekli olduğu sonucuna varılmıştır. 


\section{KAYNAKLAR}

Ajuyah, A.O., Lee, K.H., Hardin, R.T., Sim, J.S. 1991. Changes in the yield and in fatty acid composition of whole carcass and skeletal meat portions of broiler chickens fed full-fat oil seeds. Poultry Science, 70: 2304-2314.

Anonymous, 2012. http://agr.mt.gov/camelina/ (12.11.2011).

Aziza, A.E., Quezada, N., Cherian, G. 2010a. Feeding camelina sativa meal to meat-type chickens: Effect on production performance and tissue fatty acid composition. Journal of Applied Poultry Research, 19: 157-168.

Aziza, A.E., Quezada, N., Cherian, G. 2010 b. Antioxidative effect of dietary Camelina meal in fresh, stored or cooked broiler chicken meat. Poultry Science, 89: 2711-2718.

Bean, L.D., Leeson, S. 2003. Long-term effects of feeding flax seed on performance and egg fatty acid composition of brown and white hens. Poultry Science, 82: 388-394.

Cherian, G., Campbell, A., Parker, T. 2009. Egg quality and lipid composition of eggs from hens fed Camelina sativa. Journal of Applied Poultry Research, 18: 143-150.

Cherian, G. 2012. Camelina sativa in poultry diets: opportunities and challenges. In: Makkar, H.P.S, Biofuel co-products as livestock feed-opportunities and challenges, FAO, pp: 303-310.

Georgeta, C., Veronica, H., Viorica, T., Burcea, D. 2007. Use of dietary camelina (camelina sativa) seeds during the finishing period; effects on broiler performance and on the organoleptic traits of broiler meat. Zootehnie şi Biotehnologii, 40(1): 410-417.

Gonzalez, R., Leeson, S. 2001. Alternatives for enrichment of eggs and chicken meat with omega-3 fatty acids. Canadian Journal of Animal Science, 81: 295-305.

Hurtaud, C., Peyraud, J.L. 2007. Effects of feeding camelina (seeds or meal) on milk fatty acid composition and butter spreadability. Journal of Dairy Science, 90: 5134-5145.

Jaśkiewicz, T., Puzio, I., Sagan, A. 2010. The effects of dietary supplementation with CLA and Camelina sativa seeds oil on performance of broiler chickens. Acta Scientiarum Polonorum-Medicina Veterinaria, 9: 11-19.

Katar, D., Arslan, Y., Subaş1, . 2012. Ankara ekolojik koşullarında farklı ekim zamanlarının ketencik (Camelina sativa (1.) crantz) bitkisinin yağ oranı ve bileşimi üzerine olan etkisinin belirlenmesi. Tekirdağ Ziraat Fakültesi Dergisi, 9 (3): 84-90.

Kurt, O., Seyis, F. 2008. Alternatif yağ bitkisi: Ketencik (Camelina sativa (L.) Crantz). Ondokuz May1s Üniversitesi Ziraat Fakültesi Dergisi, 23 (2): 116120.
Koç, N., Önder, M. 2012. Biyodizel hammaddesi olarak ketencik. Biyoyakıt Dünyası. 16: 8-12. ISSN:13069373.

Moriel, P., Nayigihugu, V., Cappellozza, B.I., Gonçalves, E.P, Krall, J.M., Foulke, T., Cammack, K.M., Hess, W. 2011. Camelina meal and crude glycerin as feed supplements for developing replacement beef heifers. Journal of Animal Science, 89(12): 43144324.

Önder, M. 2013. Kop bölgesinde tarımı yapılabilecek yeni bir yağ bitkisi ketencik [camelina sativa (1.) crantz]. Ulusal Kop Bölgesel Kalkınma Sempozyumu, 14-16 Kasım 2013 Konya.

Patterson, P. 2011. Camelina meal for poultry. http://www.bioenergy.psu.edu/shortcourses/2011win tercrops/patterson_camelinamealvalue.pdf.

Pekel, Y., Patterson, P.H., Hulet, R.M., Acar, N., Cravener, T.L., Dowler, D.B., Hunter, J.M. 2009. Dietary camelina meal versus flaxseed with and without supplemental copper for broiler chickens: Live performance and processing yield. Poultry Science, 88: 2392-2398.

Pilgeram, A.L, Sands, D.C., Boss, D., Dale, N., Wichman, D., Lamb, P., Lu, C., Barrows, R., Kirkpatrick, M., Thompson, B., Johnson, D.L. 2007. Camelina sativa, a Montana omega-3 fuel crop. pp. 129-131, in: J. Janick and A. Whipkey (editors). Issues in New Crops and New Uses. ASHS Press, Alexandria, VA, USA.

Puzio, I., Jaśkiewicz, T., Sagan, A., Bieńko, M., Graboś, D. 2012. Effects of CLA and camelina sativa seed oil on bone properties in broiler chickens. Bulletin of Veterinary Institute in Pulawy, 56: 93-97.

Ryhänen, E.L., Perttilä, S., Tupasela, T., Valaja, J., Eriksson, C., Larkka, K. 2007. Effect of camelina sativa expeller cake on performance and meat quality of broilers. Journal of the Science Food and Agriculture. 87(8): 1489-1494.

Szumacher-Strabel, M., Cieslak, A., Zmora, P., PersKamczyc, E., Bielinska, S., Staniszb, M., Wójtowski, J. 2011. Camelina sativa cake improved unsaturated fatty acids in ewe's milk. Journal of the Science of Food and Agriculture. 91: 2031-2037.

Toncea, I., Necseriu, D., Prisecaru, T., Balint, L.N., Ghilvacs, M.I., Popa, M. 2013. The seed's and oil composition of Camelia-first romanian cultivar of camelina (Camelina sativa, L. Crantz). Romanian Biotechnological Letters. 18(5): 8594-8602.

Zubr, J. 1997. Oil -seed crop: Camelina sativa. Industrial Crops and Products, 6: 113-119. 